\title{
Musculoskeletal Disorders in Workers-risk factors: What Can We Do?
}

\author{
Mesquita CC* \\ Health School of the Polytechnic Institute of Porto, Portugal
}

\begin{abstract}
Musculoskeletal lesions are very common in workers. Studies show a wide variety of risk factors, from physical, physiological, ergonomic or psychosocial. It is known that higher the risk most affected is the health of workers The major challenge of the last few decades has been to minimize such risk factors as well as find strategies to compensate certain efforts that are inevitable to work.

The aim of this study was to check which strategies best suited to the workplace and improve the quality of life for workers.

Publications were searched from 1980 to August 2011 in several databases. Comparative controlled studies, such as randomized controlled trials, controlled clinical trials, cohort studies, of therapeutic exercises compared to control or active interventions in workers.

The study confirmed that the prevalence of musculoskeletal pain is in low back. The frequency is related with whole body vibration, as well as with prolonged sitting position, poor body posture and physical work load (lifting and carrying loads). The results of the study suggest that the repeated or constant exposure to mechanical shocks may increase the risk of low back pain. Sedentary activity was associated with higher prevalence rates of low back symptoms. Interventions involving workers, health professionals and employers working together were more consistently effective than other interventions.
\end{abstract}

It was found the strategies that seem to be most effective is to increase physical activity through the exercise and change of habits. To be effective it is necessary to involve all economic agents and health professionals.

\section{Keywords: Musculoskeletal pain; Low back pain; Workers; Exercise}

Since the early eighteenth century, the musculoskeletal disorders were recognized as being based etiological factors and occupational. However, only since the 1970 s is that occupational factors were studied using epidemiological methods, and studies that linked the work with these factors began to appear regularly in international scientific literature. Since then, the evidence resulting from the development of more than six thousand scientific articles published only address the importance of ergonomics in the workplace [1]. However, the relationship between the musculoskeletal disorders work-related and other factors, it remains a matter of debate [1]. The same kind of controversy has been the subject of study under other conditions, including cancer and lung problems, both with multifactorial causes [1].

With the increasingly competitive market nowadays productivity is the watchword, and companies seek different strategies to survive this new reality [2]. Some follow the strategy of improving quality, modifying its productivity and its organizational structure. However, the difficulties encountered in the implementation of better quality, are mainly due to the scarcity of skilled human resources in which machines are indispensable and man is considered just another element of the production system, often inadequate to their individual characteristics. In most jobs each subject carries out its activities for a specific limited period of time, almost always reduced, inducing workers to perform their duties on time, even when it endangers their health [2]. This type of conviction often leads to disability and functional limitations in activities of daily living, as well as professional, restricting the participation of the individual in society $[3,4]$.

The World Health Organization (WHO) characterized the injury as work-related multifactorial diseases due to various risk factors involved, such as work organization, physical, psychosocial and socio cultural as well as ergonomic, contributing to the cause of these problems [5]. One of the main controversies surrounding the musculoskeletal symptoms related to work is its multifactorial nature. Some study centers are not in agreement on the relationship between multiple risk factors and individual development of this disease [5]. However, musculoskeletal disorders are becoming increasingly frequent thus becoming a major problem in industrialized countries [6-9]. Represent a major cause of morbidity and have been described as being the most common symptoms of severe prolonged pain and disability in the labor force [6,7,9-12].

The European Foundation for the Improvement of Living and Working Conditions [13], points out that Portugal is the third country in the EU where more workers are missing due to musculoskeletal disorders.

In 2001, the National Institute for Occupational Safety and Health based on various publications built a conceptual model for musculoskeletal injuries. In this model, it determined possible effects resulting from the application of loads. This may be due to external or internal forces resulting from gravitational effects and dynamic loads applied. These create internal responses of muscle, ligament and joint surfaces. As the size of the load and individual factors, organizational or social, the results can trigger adaptation effects (increases in strength, endurance and physical fitness or be harmful (such as pain or even

*Corresponding author: Mesquita CC, Associate Professor, Cristina Carvalho Mesquita, PhD, MSc, Pt, Escola Superior de Tecnologia da Saúde do Porto, Rua Valente Perfeito, 322 4400-330 Vila Nova de Gaia, Portugal, E-mail: ccm@estsp.ipp.pt

Received March 05, 2013; Accepted April 25, 2013; Published April 27, 2013 Citation: Mesquita CC (2013) Musculoskeletal Disorders in Workers-risk factors: What Can We Do? Occup Med Health Aff 1: 113. doi:10.4172/2329-6879.1000113 Copyright: (๑) 2013 Mesquita CC. This is an open-access article distributed under the terms of the Creative Commons Attribution License, which permits unrestricted use, distribution, and reproduction in any medium, provided the original author and source are credited. 
structural damage to the tendons, nerves, muscles, joints or supporting tissues), which can result in painful symptoms, dysfunction or failure [13-17].

Workers are often subjected to repetitive movements and vibration, the lifting and transport of weights, incorrect postures for prolonged periods of time is sometimes long working hours [18-28]. These factors put the soft tissue tension, rising progressively to musculoskeletal disorders $[25,29,30]$.

The musculoskeletal symptoms may still arise or be exacerbated if the work involves exposure to low temperatures. Some authors [31] found a high prevalence of musculoskeletal symptoms workers in areas of very cold $\left(2^{\circ} \mathrm{C}\right)$, especially in the lower back, neck and shoulders. Other authors state that the cold reduced muscle performance, leading progressively to a voltage increase fatigue and subsequent premature [21]. Moreover, the psychosocial burden that the worker is subject, plus a weak social support and low job satisfaction develop a mechanism that stress leads to increased muscle tone and activation of pain receivers, enhancing musculoskeletal pain [29,32-34].

According to the European Foundation for the Improvement of Working Conditions Living and [13], musculoskeletal disorders more common among workers in the U.S. are low back pain (25\%) and generalized muscle pain (23\%). The musculoskeletal disorders can be measured by symptoms reported by workers, being considered as the presence of symptoms of pain, suffering or discomfort. Affect all anatomical regions of the spine and upper limb or lower [26,35-37]. However, low back pain is a condition that involves greater morbidity and disability, affecting considerable financial costs comprising $58-84 \%$ of active adults [38-45].

Low back pain can restrict the function with personal consequences, interpersonal and social, such as loss of independence, and inability to perform various activities in social life and can even interfere with basic activities such as standing, walking and dressing, reducing the quality of life as well as the many activities related to job performance [46-49].

In addition to physical factors, several studies have shown that psychosocial factors inherent in the job, as authority for decision, psychological job demands, support from supervisors, dissatisfaction and job insecurity contribute to the declining state of health workers [50-53]. Such factors appear to potentiate the pain and disability progression over time, while the physical factors are related to the acute problem [54,55].

The belief that individuals have about their pain, may lead to fear of movement/re-injury, decreased function and activity and consequent exacerbation for a chronic disability [50-53] enchanting to a decreased quality of life [56].

In recent decades, exercise has been reported as an asset in the treatment of low back pain, seemingly helping patients with chronic low back pain to resume normal activities in their employment [57]. The programs of injury prevention [58], such as promoting health and physical exercise, aim to reduce the possible risk factors [59], contributing to the reduction of direct costs of injuries and to increase productivity and quality of life [58].

The exercise programs have proven to be most effective in the prevention and treatment of back pain than conventional therapies, resulting in reduced pain and more functionality, reducing absenteeism low back pain [50]. In a recent review, the authors found strong evidence among exercise programs and prevention of back problems [60]. Another study found that there is support for it can be said that the exercise programs improve flexibility and muscle strength at the rachis [61]. However, there is still some controversy regarding the effects of exercise, found no positive effects on their intervention in industrial workers. On the other hand, a more recent study [62] found that exercise programs were effective in reducing pain and functionality but only in the short term [63]. These results may be due to communication problems or dissatisfaction and high expectations created $[64,65]$.

A well structured exercise program should decrease symptoms, pain and increased strength that enables individuals to fulfill their tasks with less effort [6,66-69]. These same exercise program specific to the lumbar region have been effective in reducing pain, reducing the required performance required for daily activities, as well as the inability [68], thus inducing a significant improvement of quality of life in individuals $[70,71]$.

Although European guidelines do not recommend the type and intensity of exercise, they recommend programs should be carried out taking into account the repeated movements and tasks that individuals perform during their work $[6,72]$. Workers should be instructed on how to perform the exercises and should reinforce the idea that the physical, social and mental are the foundations of quality of life $[6,72]$.

\section{References}

1. Bernard BP (1997) A Critical Review of Epidemiologic Evidence for Work Related Musculoskeletal Disorders of the Neck, Upper Extremity, and Low Back. National Institute for Occupational Safety and Health: Columbia-Cincinnati.

2. Costa G (2003) Shift work and occupational medicine: an overview. Occup Med (Lond) 53: 83-88.

3. Meijsen P, Knibbe HJ (2007) Work-related musculoskeletal disorders of perioperative personnel in the Netherlands. AORN J 86: 193-208.

4. Van Nieuwenhuyse A, Somville PR, Crombez G, Burdorf A, Verbeke G, et al (2006) The role of physical workload and pain related fear in the development of low back pain in young workers: evidence from the BelCoBack Study; results after one year of follow up. Occup Environ Med 63: 45-52.

5. (1985) Identification and control of work-released diseases. Report of a WHO Expert Committee. World Health Organ Tech Rep Ser 714: 1-71.

6. Airaksinen O, Brox JI, Cedraschi C, Hildebrandt J, Klaber-Moffett J, et al. (2006) Chapter 4. European guidelines for the management of chronic nonspecific low back pain. Eur Spine J 15 Suppl 2: S192-300.

7. Bigos SJ, Holland J, Holland C, Webster JS, Battie M, et al. (2009) High-quality controlled trials on preventing episodes of back problems: systematic literature review in working-age adults. Spine J 9: 147-168.

8. Borenstein DG (2000) Epidemiology, etiology, diagnostic evaluation, and treatment of low back pain. Curr Opin Rheumatol 12: 143-149.

9. Butler RJ, Johnson WG (2011) Loss reduction through worker satisfaction: the case of workers' compensation. Risk Management and Insurance Review 14 $1-26$.

10. Meerding WJ, IJzelenberg W, Koopmanschap MA, Severens JL, Burdorf A (2005) Health problems lead to considerable productivity loss at work among workers with high physical load jobs. J Clin Epidemiol 58: 517-523.

11. Rugulies R, Krause N (2005) Job strain, iso-strain, and the incidence of low back and neck injuries. A 7.5-year prospective study of San Francisco transit operators. Soc Sci Med 61: 27-39.

12. IJzelenberg W, Burdorf A (2004) Impact of musculoskeletal co-morbidity of neck and upper extremities on healthcare utilisation and sickness absence for low back pain. Occup Environ Med 61: 806-810.

13. Giaccone M (2007) Annual review of working conditions in the EU 2006-2007, in European Foundation for the Improvement of Living and Working Conditions. Office for Official Publications of the European Communities: Luxembourg

14. Byrns G, Reeder G, Jin G, Pachis K (2004) Risk factors for work-related low back pain in registered nurses, and potential obstacles in using mechanical lifting devices. J Occup Environ Hyg 1: 11-21. 
15. Keyserling WM, Sudarsan SP, Martin BJ, Haig AJ, Armstrong TJ (2005) Effects of low back disability status on lower back discomfort during sustained and cyclical trunk flexion. Ergonomics 48: 219-233.

16. Wai EK, Roffey DM, Bishop P, Kwon BK, Dagenais S (2010) Causal assessment of occupational bending or twisting and low back pain: results of a systematic review. Spine J 10: 76-88.

17. Roffey DM, Wai EK, Bishop P, Kwon BK, Dagenais S (2010) Causal assessment of occupational pushing or pulling and low back pain: results of a systematic review. Spine J 10: 544-553.

18. Ala-Mursula L, Vahtera J, Pentti J, Kivimäki M (2004) Effect of employee worktime control on health: a prospective cohort study. Occup Environ Med 61: $254-261$

19. Alipour A, Ghaffari M, Shariati B, Jensen I, Vingard E (2008) Occupational neck and shoulder pain among automobile manufacturing workers in Iran. Am J Ind Med 51: 372-379.

20. Dembe AE, Erickson JB, Delbos RG, Banks SM (2005) The impact of overtime and long work hours on occupational injuries and illnesses: new evidence from the United States. Occup Environ Med 62: 588-597.

21. Dovrat E, Katz-Leurer M (2007) Cold exposure and low back pain in store workers in Israel. Am J Ind Med 50: 626-631.

22. Guo HR (2002) Working hours spent on repeated activities and prevalence of back pain. Occup Environ Med 59: 680-688.

23. Häkkänen M, Viikari-Juntura E, Martikainen R (2001) Job experience, work load, and risk of musculoskeletal disorders. Occup Environ Med 58: 129-135.

24. Hussain T (2004) Musculoskeletal symptoms among truck assembly workers. Occup Med (Lond) 54: 506-512.

25. Jansen JP, Morgenstern H, Burdorf A (2004) Dose-response relations between occupational exposures to physical and psychosocial factors and the risk of low back pain. Occup Environ Med 61: 972-979.

26. Juul-Kristensen B, Jensen C (2005) Self-reported workplace related ergonomic conditions as prognostic factors for musculoskeletal symptoms: the "BIT" follow up study on office workers. Occup Environ Med 62: 188-194.

27. Shimizu T, Horie S, Nagata S, Marui E (2004) Relationship between selfreported low productivity and overtime working. Occup Med (Lond) 54: 52-54.

28. Tveito TH, Hysing M, Eriksen HR (2004) Low back pain interventions at the workplace: a systematic literature review. Occup Med (Lond) 54: 3-13.

29. Bonde JP, Mikkelsen S, Andersen JH, Fallentin N, Baelum J, et al. (2005) Understanding work related musculoskeletal pain: does repetitive work cause stress symptoms? Occup Environ Med 62: 41-48.

30. Kuorinka I, Patry L (1995) Participation as a means of promoting occupationa health. International Journal of Industrial Ergonomics 15: 365-370.

31. Piedrahíta H, Punnett L, Shahnavaz H (2004) Musculoskeletal symptoms in cold exposed and non-cold exposed workers. International Journal of Industrial Ergonomics 34: 271-278

32. Cherry NM, Meyer JD, Chen Y, Holt DL, McDonald JC (2001) The reported incidence of work-related musculoskeletal disease in the UK: MOSS 19972000. Occup Med (Lond) 51: 450-455.

33. Hoogendoorn WE, Bongers PM, de Vet HC, Ariëns GA, van Mechelen W, et al. (2002) High physical work load and low job satisfaction increase the risk of sickness absence due to low back pain: results of a prospective cohort study. Occup Environ Med 59: 323-328.

34. Besler A, Can F (2003) Correlation between pain, trunk muscle strength, and functional state in low back pain. The Pain Clinic 15: 415-419.

35. Kuorinka I, Jonsson B, Kilbom A, Vinterberg H, Biering-Sørensen F, et al (1987) Standardised Nordic questionnaires for the analysis of musculoskeletal symptoms. Appl Ergon 18: 233-237.

36. Enthoven P, Skargren E, Carstensen J, Oberg B (2006) Predictive factors for 1 -year and 5-year outcome for disability in a working population of patients with low back pain treated in primary care. Pain 122: 137-144.

37. Punnett L, Wegman DH (2004) Work-related musculoskeletal disorders: the epidemiologic evidence and the debate. J Electromyogr Kinesiol 14: 13-23

38. Airaksinen O, Brox JI, Cedraschi C, Hildebrandt J, Klaber-Moffett J, et al. (2006)
Chapter 4. European guidelines for the management of chronic nonspecific low back pain. Eur Spine J 15 Suppl 2: S192-300.

39. Alexopoulos EC, Burdorf A, Kalokerinou A (2003) Risk factors for musculoskeletal disorders among nursing personnel in Greek hospitals. Int Arch Occup Environ Health 76: 289-294.

40. Alexopoulos EC, Tanagra D, Konstantinou E, Burdorf A (2006) Musculoskeleta disorders in shipyard industry: prevalence, health care use, and absenteeism. BMC Musculoskelet Disord 7: 88 .

41. Alipour A, Ghaffari M, Shariati B, Jensen I, Vingard E (2008) Occupational neck and shoulder pain among automobile manufacturing workers in Iran. Am J Ind Med 51: 372-379.

42. Bongers PM, ljmker S, van den Heuvel S, Blatter BM (2006) Epidemiology of work related neck and upper limb problems: psychosocial and personal risk factors (part I) and effective interventions from a bio behavioural perspective (part II). J Occup Rehabil 16: 279-302.

43. Deyo RA, Battie M, Beurskens AJ, Bombardier C, Croft P, et al. (1998) Outcome measures for low back pain research. A proposal for standardized use. Spine (Phila Pa 1976) 23: 2003-2013.

44. Dunn KM, Jordan K, Croft PR (2006) Characterizing the course of low back pain: a latent class analysis. Am J Epidemiol 163: 754-761.

45. Dunning KK, Davis KG, Cook C, Kotowski SE, Hamrick C, et al. (2010) Costs by industry and diagnosis among musculoskeletal claims in a state workers compensation system: 1999-2004. Am J Ind Med 53: 276-284.

46. Ceran F, Ozcan A (2006) The relationship of the Functional Rating Index with disability, pain, and quality of life in patients with low back pain. Med Sci Monit 12: CR435-439.

47. Hilfiker R, Bachmann LM, Heitz CA, Lorenz T, Joronen $\mathrm{H}$, et al. (2007) Value of predictive instruments to determine persisting restriction of function in patients with subacute non-specific low back pain. Systematic review. Eur Spine J 16 : $1755-1775$.

48. Loisel P, Buchbinder R, Hazard R, Keller R, Scheel I, et al. (2005) Prevention of work disability due to musculoskeletal disorders: the challenge of implementing evidence. J Occup Rehabil 15: 507-524.

49. van Tulder M, Malmivaara A, Koes B (2007) Repetitive strain injury. Lancet 369: $1815-1822$

50. Moffett JK, Torgerson D, Bell-Syer S, Jackson D, Llewlyn-Phillips H, et al. (1999) Randomised controlled trial of exercise for low back pain: clinical outcomes, costs, and preferences. BMJ 319: 279-283.

51. Ferreira PL (2000) [Development of the Portuguese version of MOS SF-36. Part II --Validation tests]. Acta Med Port 13: 119-127.

52. Arnold LM, Witzeman KA, Swank ML, McElroy SL, Keck PE Jr (2000) Healthrelated quality of life using the SF-36 in patients with bipolar disorder compared with patients with chronic back pain and the general population. J Affect Disord 57: 235-239.

53. Edwards JA, Laar DV, Easton S, Kinman G (2009) The Work-related Quality of Life Scale for Higher Education Employees. Qual Higher Educ 15: 207-219.

54. Urquhart DM, Bell RJ, Cicuttini FM, Cui J, Forbes A, et al. (2008) Negative beliefs about low back pain are associated with high pain intensity and high level disability in community-based women. BMC Musculoskelet Disord 9: 148

55. Vlaeyen JW, Kole-Snijders AM, Boeren RG, van Eek H (1995) Fear of movement/(re)injury in chronic low back pain and its relation to behavioral performance. Pain 62: 363-372.

56. van Tulder MW, Koes B, Malmivaara A (2006) Outcome of non-invasive treatment modalities on back pain: an evidence-based review. Eur Spine $\mathrm{J} 1$ : S64-81.

57. Rainville J, Hartigan C, Martinez E, Limke J, Jouve C, et al. (2004) Exercise as a treatment for chronic low back pain. Spine J 4: 106-115.

58. Salinas AM, Villarreal E, Nuñez GM, Garza ME, Briones H, et al. (2002) Health interventions for the metal working industry: which is the most cost-effective? A study from a developing country. Occup Med (Lond) 52: 129-135.

59. Eriksen HR, Ihlebaek C, Mikkelsen A, Grønningsaeter H, Sandal GM, et al. (2002) Improving subjective health at the worksite: a randomized controlled trial of stress management training, physical exercise and an integrated health programme. Occup Med (Lond) 52: 383-391. 
Citation: Mesquita CC (2013) Musculoskeletal Disorders in Workers-risk factors: What Can We Do? Occup Med Health Aff 1: 113. doi:10.4172/23296879.1000113

60. Bigos SJ, Holland J, Holland C, Webster JS, Battie M, et al. (2009) High-quality controlled trials on preventing episodes of back problems: systematic literature review in working-age adults. Spine J 9: 147-168.

61. Rainville J, Hartigan C, Martinez E, Limke J, Jouve C, et al. (2004) Exercise as a treatment for chronic low back pain. Spine J 4: 106-115.

62. Brox JI, Storheim K, Grotle M, Tveito TH, Indahl A, et al. (2008) Systematic review of back schools, brief education, and fear-avoidance training for chronic low back pain. Spine J 8: 948-958.

63. IJzelenberg H, Meerding WJ, Burdorf A (2007) Effectiveness of a back pain prevention program: a cluster randomized controlled trial in an occupational setting. Spine (Phila Pa 1976) 32: 711-719.

64. Goldby LJ, Moore AP, Doust J, Trew ME (2006) A randomized controlled trial investigating the efficiency of musculoskeletal physiotherapy on chronic low back disorder. Spine (Phila Pa 1976) 1: 1083-1093.

65. Sherman KJ, Cherkin DC, Erro J, Miglioretti DL, Deyo RA (2005) Comparing yoga, exercise, and a self-care book for chronic low back pain: a randomized, controlled trial. Ann Intern Med 143: 849-856.

66. Arnold LM, Witzeman KA, Swank ML, McElroy SL, Keck PE Jr (2000) Healthrelated quality of life using the SF-36 in patients with bipolar disorder compared with patients with chronic back pain and the general population. J Affect Disord 57: 235-239.

67. Carroll LJ, Whyte A (2003) Predicting chronic back pain sufferers' intention to exercise. British J Ther Rehab 10: 53-58.

68. Lang E, Liebig K, Kastner S, Neundörfer B, Heuschmann P (2003) Multidisciplinary rehabilitation versus usual care for chronic low back pain in the community: effects on quality of life. Spine J 3: 270-276.

69. Moffet J K (1999) Stabilization Mechanisms of the Lumbar Spine. Physiotherapy 12: $72-79$.

70. Merkesdal S, Mau W (2005) Prediction of costs-of-illness in patients with low back pain undergoing orthopedic outpatient rehabilitation. Int $\mathrm{J}$ Rehabil Res 28: 119-126.

71. van Poppel MN, Hooftman WE, Koes BW (2004) An update of a systematic review of controlled clinical trials on the primary prevention of back pain at the workplace. Occup Med (Lond) 54: 345-352.

72. Burton AK, Balagué F, Cardon G, Eriksen HR, Henrotin Y, et al. (2006) Chapter 2. European guidelines for prevention in low back pain : November 2004. Eur Spine J 15 Suppl 2: S136-168. 